\title{
Correction to: An efficient system for homology-dependent targeted gene integration in medaka (Oryzias latipes)
}

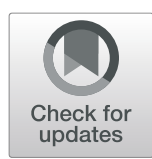

Yu Murakami ${ }^{1}$, Satoshi Ansai ${ }^{1,2}$, Akari Yonemura ${ }^{1}$ and Masato Kinoshita ${ }^{1 *}$

\section{Correction to: Zoological Lett}

https://doi.org/10.1186/s40851-017-0071-x

Please note that there are two errors present in the tables of the published article [1].

Firstly, the value ' 3 ' is missing from the 5 th row of the 'GFP+' column of Table 1 .

Secondly, the gene sequence given for 'Candidate \#28' in Additional file 6: Table S3 is incorrect. The gene sequence should be 'TCTTCGGCCTAGACTGCGAGG'.

Table 1 Comparison of integrate efficiency among each of donor plasmids

\begin{tabular}{llllll}
\hline Length of homology arms & Bait sequences & Survival at 4 dpf & No GFP & GFP+ & Integrate efficiency (\%) \\
\hline $500 \mathrm{bp}$ & + & 70 & 53 & 17 & 24.3 \\
$500 \mathrm{bp}$ & - & 62 & 56 & 6 & 9.7 \\
$40 \mathrm{bp}$ & + & 64 & 61 & 3 & 4.7 \\
$20 \mathrm{bp}$ & + & 110 & 108 & 2 & 1.9 \\
\hline
\end{tabular}

\section{Additional file}

Additional file 6: Table S3. Potential off-target sites of 7 candidates of bait sequence that selected in the first screening and previously reported bait sequences. Potential off-target sites are defined as genomic sequence harboring up to $2 \mathrm{bp}$ mismatches in the total $18 \mathrm{bp}$ sequences and a NGG PAM. (XLSX $10 \mathrm{~kb})$
Published online: 08 July 2019

\section{Reference}

1. Murakami, et al. An efficient system for homology dependent targeted gene integration in medaka (Oryzias latipes). 2017;3:10. https://doi.org/10. 1186/s40851-017-0071-x

\section{Author details}

'Division of Applied Bioscience, Graduate School of Agriculture, Kyoto University, Kitashirakawa-Oiwake-cho, Sakyo-ku, Kyoto 606-8502, Japan. ${ }^{2}$ Present address: Division of Ecological Genetics, Department of Population Genetics, National Institute of Genetics, Yata 1111, Mishima, Shizuoka 411-8540, Japan

\footnotetext{
* Correspondence: kinoshit@kais.kyoto-u.ac.jp

'Division of Applied Bioscience, Graduate School of Agriculture, Kyoto University, Kitashirakawa-Oiwake-cho, Sakyo-ku, Kyoto 606-8502, Japan Full list of author information is available at the end of the article
}

(c) The Author(s). 2019 Open Access This article is distributed under the terms of the Creative Commons Attribution 4.0 International License (http://creativecommons.org/licenses/by/4.0/), which permits unrestricted use, distribution, and reproduction in any medium, provided you give appropriate credit to the original author(s) and the source, provide a link to the Creative Commons license, and indicate if changes were made. The Creative Commons Public Domain Dedication waiver (http://creativecommons.org/publicdomain/zero/1.0/) applies to the data made available in this article, unless otherwise stated. 